Poznańskie Studia Teologiczne 27(2013), s. 61-68.

Bogdan Ferdek

Papieski Wydział Teologiczny

Wrocław

\title{
'Oikoumene' as an Instrument of Peace: the Catholic-Orthodox Dialogue in light of the Ravenna Document
}

Paul VI's encyclical entitled Ecclesiam Suam was published in 1964. Its third chapter deals with the topic of dialogue. Within the sphere of dialogue, the Pope distinguishes four circles.

The first circle of dialogue is mankind. The contribution of the Church to the dialogue with mankind consists in consolidating moral truths of conscience. The significance of these truths was emphasized by Reinhold Schneider, a German poet, theologian, and philosopher. He claimed that all great catastrophes in the history of mankind first occurred in the sphere of morality and only later manifested themselves in wars.

The second circle comprises worshippers of the One God. Referring to this circle, Paul VI wrote:

But we do not wish to turn a blind eye to the spiritual and moral values of the various non-Christian religions, for we desire to join with them in promoting and defending common ideals in the spheres of religious liberty, human brotherhood, education, culture, social welfare and civic order. Dialogue is possible in all these great projects, which are our concern as much as theirs $[\ldots]^{1}$

In the circle of worshippers of One God, the scope of dialogue is being continually extended to such areas as the defence of the primacy of God's law over man's law, the defence of marriage, and family as well as defence of human life, to name but a few. Undeniably, a substantial contribution to the sphere of interfaith dialogue is that of Horst Bürkle. In his monograph, Erkennen und Bekennen. Schriften zum missionarischen Dialog, we can find theological foundations for interreligious dialogue. The aim of dialogue between religions is neither the creation of any such entity as United Religions nor any other institution modelled after the United Nations or the like. It is true that we must aim at finding common values. However, at the same time we also need to maintain our own

\footnotetext{
${ }^{1}$ Pope Paul VI, Ecclesiam Suam, par. 108. Encyclicals. <http://www.vatican.va/phome_en.htm>. [Accessed 9 Nov 2011].
} 
spiritual wealth and identity. ${ }^{2}$ Therefore, interreligious dialogue is in fact an intercultural dialogue. As such, it is supposed to expose the cultural consequences that may ensue from our basic religious presumptions.

The third circle comprises separated Christians. According to the words of Pope Paul VI, it is especially the matters of contention which should be addressed in dialogue within this circle. One of these divisive issues is that of papal primacy $(\pi \rho \omega \tau \varepsilon i ́ o)$.

The dialogue concerning the issue of papal primacy ( $\pi \rho \omega \tau \varepsilon i ́$ ) has been conducted within the Joint International Commission for Theological Dialogue Between the Catholic Church and the Orthodox Church. Kallistos Ware is among its members. The present state of the dialogue is delineated in the Ravenna document entitled Ecclesiological and Canonical Consequences of the Sacramental Nature of the Church: Ecclesial Communion, Conciliarity and Authority. On the basis of this document, we can address those questions concerning how the Orthodox and the Catholics understand primacy ( $\pi \rho \omega \tau \varepsilon i o)$, the extent to which they are already united in their interpretation, and what remains a matter of contention with an eye to the possibility of future agreement.

The Ravenna document was signed on the $13^{\text {th }}$ of October 2007. Its structure, apart from the introduction and conclusion, comprises two chapters. The first of them, drawing on Scripture and Tradition, presents the theological basis of conciliarity and primacy ( $\pi \rho \omega \tau \varepsilon i ́$ ) in the Church. Subsequently, the second chapter depicts their realisation on the local, regional, and universal level of the Church's life. Conciliarity and primacy in the Church are most fully justified on the grounds of the essential dogma of Christianity - the dogma of the Holy Trinity. This dogma is often considered to be irrelevant to everyday life, resembling some sort of a philosophical theory, called a 'cross for human thinking'. However, it helps us understand the Church. The Church is the icon of the Holy Trinity both for Eastern and Western theology. That is why, when reflecting upon the Church, we have to take the dogma of the Holy Trinity as our starting point.

\section{Primacy ( $\pi \rho \omega \tau \varepsilon i ́ o)$ and Conciliarity as an Icon of the Holy Trinity}

We can distinguish two models of understanding the mystery of the Holy Trinity, the Eastern and the Western. The Eastern model concentrates on the three persons and their communion (koinonia), whereas the Western takes as its grounding premise the Divine Nature which the three persons share. The Ravenna Document should be examined in light of the Eastern model of the Holy Trinity. According to this model, the Father has primacy among equal persons. As

\footnotetext{
${ }^{2}$ H. Bürkle, Erkennen und Bekennen. Schriften zum missionarischen Dialog, St Ottilien 2010, 9.
} 
the metropolitan bishop Kallistos Ware asserts: "The first person of the Trinity, God the Father, is the 'fountain' of the Godhead, the source, cause or principle of origin for the other two persons. He is the bond of unity between the three. [...] The other two persons are each defined in terms of their relationship to the Father: the Son is 'begotten' by the Father, the Spirit 'proceeds' from the Father". ${ }^{3}$ Since the Church is an icon of the three persons, among which God the Father holds primacy, it follows that also within the Church there must be a place for the primacy. Yet, in the Holy Trinity, all three persons act together and therefore, according to Metropolitan Kallistios Ware, it can be said that "God is 'social', 'conciliar'; there is something in him that corresponds to the notion of sobornost". ${ }^{4}$ It would follow that since the Church is an image of the conciliar God, this conciliarity should also be mirrored in its nature.

Being the icon of the Holy Trinity, the Church must at the same time be conciliar in nature and be internally characterized by primacy. Conciliarity and protos must be visible on all planes of the Church's life, i.e. local, regional, and universal. According to the Ravenna document, "Primacy and conciliarity are mutually interdependent. That is why primacy at the different levels of the life of the Church, local, regional, and universal, must always be considered in the context of conciliarity, and conciliarity likewise in the context of primacy". ${ }^{5}$ As far as primacy at all planes of the life of the Church is concerned, the document affirms that "primacy at all levels is a practice firmly grounded in the canonical tradition of the Church". Moreover, it asserts that "while the fact of primacy at the universal level is accepted by both East and West, there are differences of understanding with regard to the manner in which it is to be exercised, and also with regard to its scriptural and theological foundations". 6

\section{The Primacy ( $\pi \rho \omega \tau \varepsilon i ́ o)$ on the Universal Level of the Church}

Since the Church is an icon of the Holy Trinity, it is not only conciliar in nature, but is also characterised by primacy modelled after the Father, who has primacy between the Son and the Holy Spirit, both equal to him in the Holy Trinity. The primacy in the Church is visible on the local, regional, and universal planes. On the local plane, it is the bishop who holds primacy in relation to the

\footnotetext{
${ }^{3}$ Kallistos Ware, The Orthodox Way, New York 1995, 32.

${ }^{4}$ Kallistos Ware, Human Person as an Icon of the Trinity. The Website of St. Nicholas Church of Portland. Articles. <http://www.stnicholaspdx.org/>. [Accessed 9 Nov 2011].

${ }^{5}$ Ecclesiological and Canonical Consequences of the Sacramental Nature of the Church: Ecclesial Communion, Conciliarity and Authority. Ravenna 13 Oct 2007. <http://www.pcf.va>. [Accessed 9 Nov 2011].

${ }^{6}$ Ibid.
} 
priests and congregation of the local church community. On the regional level, bishops are to acknowledge the primacy of the metropolitan and, hence, in decisions of greater importance, should always await the metropolitan's consent. At the same time, the metropolitan should refrain, in matters of even greater significance, from arriving at decisions without the counsel of bishops from the archdiocese. Lastly, on the universal level, the Bishop of Rome has primacy over other patriarchs.

The primacy of the Bishop of Rome cannot, however, replace the Church's conciliar structure. The Bishop of Rome operates neither above the Church nor beyond it, but rather within it. Meanwhile, the papacy has exhibited a tendency towards overruling the Church's conciliarity. One classical example of such conduct is the case of the Filioque. The Western theologian's conviction of the Holy Spirit's proceeding not only from the Father, as stated in the Gospel according to John $(15,26)$, but also from the Son, was incorporated into the Nicene-Constantinopolitan Creed by Pope Benedict VIII in 1014. The Orthodox Church sees the introduction of the Filioque as "unauthorized addition - for it was inserted into the Creed without the consent of the Christian East". ${ }^{7}$ Having introduced such changes, the Pontiff positioned himself above the council and thereby upsetting the balance between the primacy of the Bishop of Rome and the council when the Church should necessarily seek to maintain that balance. One example of an attempt to act in accordance with that principle is the cooperation of Pope Leo with the Fathers of the Council of Chalcedon. As Klaus Schatz in his historical study confirms, "at Constantinople III (680-681) and Nicea II (787) the popes, like Leo at Chalcedon, pointed the way for the council through dogmatic letters. They did not expect their decisions to be accepted by the councils without discussion, and they always acknowledged the councils' independent authority". ${ }^{8}$ Even though the papal legates only wanted the council to sanction the Pope's letter, a new definition of council, proposed by the council itself, emerged during the session. In turn, Pope Leo voiced his objection to 'Canon 28' of Chalcedon, which decreed that "the most holy throne of New Rome, [...] the city which is honoured with the Sovereignty and the Senate, and enjoys equal privileges with the old imperial Rome, should in ecclesiastical matters also be magnified as she is, and rank next after her". ${ }^{9}$ Pope Leo justified his appeal by referring to the Nicene ruling, according to which it was Alexandria that was to be ranked after Rome, followed by Antioch ('Canon 6'). The Pope also invoked the theory concerning the traditional triad of capitals of Peter championed by the Council of Rome in the year 382. It stated that it was also Alexandria and Antioch that were

\footnotetext{
${ }^{7}$ Kallistos Ware, The Orthodox Way, op. cit., 32.

${ }^{8}$ K. Schatz, Papal Primacy: from its Origins to the Present, Collegeville 1996, 49-50.

${ }^{9}$ P. Schaff, The Seven Ecumenical Councils, Edinburgh 2005, 383.
} 
assigned a prominent role in the Church because of their special relation to the life of Peter. Antioch is the city of Peter's long activity. Alexandria, in turn, is included in the tradition of Peter through Mark, his disciple. That is why Constantinople has long tried to have its connection to Rome established through the person of Andrew, the brother of Peter. The Bishops of Rome occupied a crucial role in the proceedings of councils. Although not always present, they were always involved in the deliberations.

The primacy of the Bishop of Rome has to be understood in the light of the words of Ignatius of Antioch. In his Letter to the Romans he wrote:

Ignatius who is also called Theophorus, to the Church which has obtained mercy, through the majesty of the Most High Father, and Jesus Christ, His only-begotten Son; the Church which is beloved and enlightened by the will of Him that wills all things which are according to the love of Jesus Christ our God, which also presides in the place of the region of the Romans, worthy of God, worthy of honour, worthy of the highest happiness, worthy of praise, worthy of obtaining her every desire, worthy of being deemed holy, and which presides over love, is named from Christ, and from the Father. ${ }^{10}$

Thus, the primacy of the Bishop of Rome consists in his presiding in love. During Pope Paul VI's visit to the Fanar in 1967, Patriarch Athenagoras acknowledged him as the successor of Peter, most worthy of veneration, as the first among us, and presiding in love. Thus, the high dignitary of the Church uttered a very important formulation of the role of primacy in the first millennium. Also Joseph Ratzinger maintains that Rome should not demand anything more than to be recognized as holding the presidency in love.

What still needs to be reassessed is the biblical foundation for the primacy of the Bishop of Rome. Catholic theology most often cites the Gospel of Mathew saying "You are Peter (or Rock) and on this rock I will build my Church" $(16,18)$. However, it is important to note St. Augustine's words. He taught that the Church indeed rests on Peter, though not on him as an individual human being, but on his faith in Christ, ("Non enim dictum est illi: tu es petra, sed: tu es Petrus. Petra autem erat Christus"). Thus, the sole foundation of the Church is Christ. ${ }^{11}$

The Ravenna Document, however, does not exhaust the subject of the primacy of the Bishop of Rome. It is merely the beginning of a discussion on this issue. The dialogue will be resumed in the next session. Its topic is to be "The Role of the Bishop of Rome in the Communion of the Church in the First Millenium".

${ }^{10}$ Ignatius of Antioch, The Epistle of Ignatius to the Romans, in: Anti-Nicene Fathers, eds. A. Roberts, J. Donaldson, Massachusetts 2004, vol. I, 73.

${ }^{11}$ J. Ratzinger, Volk und Haus Gottes in Augustins Lehre von der Kirche, St. Ottilien 1992, 180. 


\section{The Possibility of Reinterpretation or Correction of the Western Understanding of Papal Primacy ( $\pi \rho \omega \tau \varepsilon i ́ o)$}

The Western understanding of papal primacy is presented in the Pastor Aeternus Constitution of the First Vatican Council from the $18^{\text {th }}$ July 1870. According to the Constitution:

Wherefore we teach and declare that, by divine ordinance, the Roman Church possesses a pre-eminence of ordinary power over every other Church, and that this jurisdictional power of the Roman Pontiff is both episcopal and immediate. Both clergy and faithful, of whatever rite and dignity, both singly and collectively, are bound to submit to this power by the duty of hierarchical subordination and true obedience, and this not only in matters concerning faith and morals, but also in those which regard the discipline and government of the Church throughout the world. ${ }^{12}$

The Pastor Aeternus Constitution comprises four chapters: the first deals with Christ bestowing primacy on Peter, the second presents the continuation of the tradition of primacy, the third explores its character as the highest jurisdictional power, and the fourth deals with the doctrine of papal infallibility. While the first two chapters contain well consolidated claims, it is the last two which cover new and controversial statements. The old controversy over conciliarity is here resolved in the Church's favour. The balance between a council's power and the papal primacy was upset to the advantage of the latter. This means a new model of the Church, whose sacramental structure has been replaced with a legal one. As Joseph Ratzinger recognized, it may have appeared that the sacramental structure of the Church was abandoned, but he answers this fear by asserting that the papacy is not sacramental in nature. He states that it is a legally sanctioned institution. $^{13}$

Meanwhile, Orthodox theology maintains that the fundamental function of the Church is that of mediating grace through the sacraments. It would follow that, within the Church, power is in the hands of those who administer the sacraments. This establishes a radical division in the Church, a division between its lay and sacerdotal members, ordo laicalis and ordo sacerdotalis. ${ }^{14}$ Therefore, the East is calling for a rejection of the doctrine concerning papal primacy from 1870 and, consequently, the annulment of the doctrines which are based on it, that is, the doctrines of Filioque, the Immaculate Conception, and the Assumption.

\footnotetext{
${ }^{12}$ Decrees of the First Vatican Council. Papal Encyclicals Online. $<$ http://www.papalencyclic als.net>. [Accessed 9 Nov 2011].

${ }^{13}$ Joseph Cardinal Ratzinger, Principles of Catholic Theology. Building Stones for a Fundamental Theology, San Francisco 1987, 195.

${ }^{14} \mathrm{Ph}$. Sherrad, Church, papacy and schism, Limni 2009, 51-52.
} 
When attempting to reinterpret the Western understanding of the primacy of the Bishop of Rome, it is crucial that radical demands be avoided. As Joseph Ratzinger asserts, an example of such a radical demand would be for the West to impose on the East an ultimate recognition of papal primacy in the shape in which it is presented in the 1870 document. ${ }^{15}$ By rejecting this claim, it cannot be maintained that the definition of papal primacy from Pastor Aeternus is to be regarded as the only possible one for all Christians. What was possible throughout the whole millennium cannot become impossible now. Therefore, in its teachings on the issue of the primacy, the West does not have to demand from the East anything more than what was formulated and practised in the first millennium. ${ }^{16}$

A reinterpretation of the primacy of the Bishop of Rome could be conducted in a comparable manner to the alteration made to the formula for Holy Orders by Pius XII in Sacramentum Ordinis in 1947. The Council of Florence in the Decree for the Armenians from 1439 established that an essential element in conferring Orders was the delivery of the chalice with wine and the paten with bread. This gratuitous addition to the original sacrament was annulled by Pius XII. This entailed a conscious return to the tradition of the Ancient Church and, by the same token, to the Eastern Orthodox Church. It was thereby an amendment to the Western tradition made in accordance with the norms of the Universal Church. ${ }^{17}$ The Western tradition of primacy could be likewise amended in light of the tradition of the Ancient Church. It would be all the more possible if the status of the councils which were held in the West in the second millennium were reassessed. If they were to be treated not as universal councils, but rather as synods of the Western Church, the Pastor Aeternus Constitution would acquire a different status.

The Ravenna document points to the urgency of the question regarding the normative significance and meaning of the Western councils as compared to the seven universal councils of the first millennium. All in all, it appears that a revision of the Pastor Aeternus Constitution is possible, just as a revision to the teachings of the Council of Florence concerning Holy Orders was possible.

According to Imre von Gaal, the unity of Christians "is the result of spiritually living Christ «s charity, not of an administrative approach". ${ }^{18}$ Therefore, as Benedict XVI suggests, what is already possible on the level of theology, must take time to mature spiritually in order that it become possible to implement it in the sphere of reality in the Church (269). ${ }^{19}$ This spiritual maturation is also possible through patient dialogue.

\footnotetext{
${ }^{15}$ J. Ratzinger, Principles of Catholic Theology, op. cit., 197.

${ }^{16}$ Ibid, 199.

${ }^{17}$ Ibid, 240.

${ }^{18}$ E. de Gaál, The Theology of Pope Benedict XVI, New York, 2010, 197.

${ }^{19}$ J. Ratzinger, Principles of Catholic Theology, op. cit., 199.
} 


\section{Oikoumene jako narzędzie pokoju: dialog katolicko-prawosławny w świetle dokumentu z Rawenny}

\section{Streszczenie}

Międzynarodowa Komisja Wspólna ds. Dialogu między Kościołem Rzymskokatolickim a Cerkwią Prawosławną prowadzi dialog poświęcony prymatowi papieskiemu. Aktualny stan dialogu na temat prymatu oddaje dokument z Rawenny: Ecclesiological and Canonical Consequences of the Sacramental Nature of the Church. Ecclesial Communion, Conciliarity and Authority. Soborowość i prymat w Kościele znajdują najgłębsze uzasadnienie w najważniejszym chrześcijańskim dogmacie o Trójcy Świętej. Dla teologii wschodniej i zachodniej Kościół jest bowiem ikoną Trójcy Świętej. Dlatego też refleksja nad nim musi wychodzić od dogmatu o Trójcy Świętej. Na dokument z Rawenny trzeba spojrzeć w świetle wschodniego modelu Trójcy Świętej. Według niego wśród równych sobie osób boskich osoba Ojca jest protos. Dwie pozostałe osoby są określane w kontekście ich związku z Ojcem: Syn został zrodzony przez Ojca, Duch od Ojca pochodzi. Skoro Kościół jest obrazem boskich osób, z których pierwsza jest protos, to musi w nim być miejsce na owo protos. Jednak w Trójcy Świętej wszystkie trzy osoby działają razem i jest w Nim coś, co koresponduje z pojęciem „soborowość”. Skoro więc Kościół jest obrazem konsyliarnego Boga, to do jego istoty należy również soborowość. Kościół będący ikoną Trójcy Świętej musi być równocześnie Kościołem soborowym i Kościołem mającym protos. Soborowość i protos muszą być widoczne na wszystkich płaszczyznach Kościoła: lokalnej, regionalnej i uniwersalnej. Na płaszczyźnie uniwersalnej jest zatem miejsce na prymat Biskupa Rzymu, który powinien być jednak zreinterpretowany w duchu starożytnego Kościoła. Reinterpretacja prymatu biskupa Rzymu mogłaby się dokonać analogicznie do korekty materii sakramentu święceń dokonanej przez Piusa XII w Sacramentum ordinis z 1947 roku. Sobór we Florencji w Dekrecie dla Ormian z 1439 roku określił, że istotnym elementem udzielania święceń jest podanie kielicha z winem i pateny z chlebem. Natomiast Pius XII uznał za materię sakramentu święceń włożenie rąk. Równało się to świadomemu powrotowi do tradycji Kościoła starożytnego, a tym samym i Kościoła Wschodu. W ten sposób forma, która w Kościele rzymskim - ale nie w Kościele powszechnym - obowiązywała przez całe wieki, została zniesiona jako partykularna forma Zachodu. Analogicznie można by dokonać korekty zachodniej tradycji prymatu biskupa Rzymu w świetle tradycji Kościoła starożytnego.

\section{Słowa kluczowe}

ekumenizm, dialog, katolicki, prawosławny, Rawenna, dokument

\section{Keywords}

ecumenism, dialogue, catholic, orthodox, Ravenna, document 